\title{
Equality and Diversity in the Classroom: A Comparison of Students' and Teachers' Attitudes in Six European Countries
}

\section{Abstract}

Globalisation and increased mobility of people within the EU have led to increased immigration and greater diversity within many EU countries, which has affected the composition of workplaces and classrooms. This includes diversity in terms of nationality, as well as ethnic, racial and religious diversity. This article expands awareness of diversity issues in the workplace to classrooms. It is based on a cross-cultural comparative study of the attitudes of secondary school students and their teachers in six European countries: Ireland, the UK, France, Latvia, Italy and Spain. The sample included 320 students and 208 teachers for a total of 528 respondents. The article compares and contrasts attitudes towards nonnational students, ethnic and religious minorities and disabled students, as well as gender issues, bullying and general perceptions of equality and diversity. It demonstrates that there is a need for teachers to have the skills and competencies to deal effectively with this new environment. The study contributes to teacher training development and discusses how to create a more inclusive classroom.

Keywords: Diversity, social inclusion, social cohesion, equality, Europe, students, teachers 


\section{Introduction}

Globalisation and increased mobility of people within the EU have led to increased immigration and greater diversity within many EU countries, which has affected the composition of workplaces and classrooms. This includes diversity in terms of nationality, as well as ethnic, racial and religious diversity. In addition, EU social and economic policies, which were initially focused on gender equality, beginning in the 1970s, are now encouraging the entry into the workplace of other groups who have previously been excluded, including older workers and those with disabilities (Fine-Davis et al., 2005a, 2005b).

The inclusion of migrants into various sectors of society is a highly important objective of European immigration and integration policy. Its importance is reflected in a number of policy meetings, agendas and strategic frameworks, not least the Lisbon Agenda and the recently adopted strategic framework for European cooperation in education and training 'ET 2020'. Several studies have looked at the economic effects of post-enlargement migration across different European countries (e.g. Barrett and McCarthy, 2008; Brenke and Zimmermann, 2007; Kahanec and Zimmermann, 2009), impacts of the current economic downturn on employment levels and emigration/immigration (e.g. Papademetriou et al. 2010; Fix et al. 2009; Ruhs 2009), and on discrimination, tolerance and diversity policies in the workplace (Carrel et al., 2000; Saji, 2004; Allen et al., 2004; Bagshaw, 2004; Fassmann, 2009).

Similarly, there is a relatively large body of educational research relevant to our study that deals with issues of immigrant incorporation, equality and diversity in schools. A number of studies have looked at factors affecting the educational performance of migrant students and strategies of integrating them into schools and society at large (e.g. Eurydice 2004, 2009; Buchmann and Parrado 2006; Heckmann, 2008; Nusche, 2009; OECD, 2006, 2010), effects of intercultural education, diversity policies and measures (e.g. Tikly et al., 2006; Heckmann, 2005; Schofield, 2006; Garreta Bochaca, 2006; Gundara and Jacobs, 2000), and perceptions of religious, ethnic and cultural diversity and the impact on schools (e.g. Jackson et al. 2007; Knauth et al., 2008; Valk et al., 2009). This research suggests for instance that immigrant children fare better scholastically in countries with high investment in early childhood education. Moreover, it is the single school that matters, i.e. this includes the school's ability to educate and raise the performance of migrant group students. Good schools are also good 
for the integration of migrant children. Several FP6 and FP7 projects (such as INCLUD-ED, EMILIE, EDUMIGROM, YIPPEE and ACCEPT PLURALISM) have also engaged with questions of how equality and diversity are perceived and addressed in today's classrooms.

European societies rely on different models to address diversity in education, with different potential consequences for the experiences youth have in schools. For example, Germany, Greece and Ireland prefer the term interculturalism and intercultural education. In contrast, Britain, the Netherlands, Canada, the United States and Malaysia have historically worked with the concept of multiculturalism (see Faas, 2010). Furthermore, Faas (2011) who compared the geography, history and citizenship education curricula in Greece, Germany and England, argued that the relationship between European and multicultural values was rather different and dependent on the school subject. Whilst history was found to be ethnocentric in all three countries - albeit to varying degrees - Greek geography and citizenship curricula veered between ethnocentrism and Europeanism. In contrast, in England, macro-political notions of multicultural Britishness were reinforced in geography and citizenship education. Following national political trends, German curricula privileged national and European topics, but attempts were made to address diversity, particularly in geography. The work of Koopmans et al. $(2005,2012)$ is equally indicative of the range of national policy-practice links, arguing that cross-national differences continue to exist due to different historical legacies and that these have not become smaller over the past three decades.

The role of education in integrating migrants and enhancing social cohesion appears to have been accepted and recognised at official level. While the difficulty of current school systems to tackle this issue is now recognised, possible routes for modification have been suggested. These are expressly targeted at addressing the recent and present reality of increased 'human mobility' from within and outside Europe. The involvement of the EU is viewed as necessary by many, notably because one of the four freedoms guaranteed by the Union concerns the ability to move across the EU (the principle of free movement of persons) - a mobility that is at times hampered by the inadequacies of school systems to deal with the specific needs of children on the move. The main emphasis of recent EU level initiatives is not on the impact that better schooling may have on the political participation of pupils with a migrant background but on social cohesion. The concept of social cohesion advocates a sense of collectivity and civic unity within schools, companies and wider society. The guiding logic of European policy documents is the better integration of migrants into society and more 
particularly into the labour market (for a more detailed discussion of European-level policy documents, see Faas et al., 2013). Expanding the awareness of diversity issues beyond the workplace to the classroom is the focus of this study.

In its 2001 report to the European Council, the Education, Youth and Culture Council asserted that in order to fulfill the objectives of the Lisbon agenda, a vision of tolerance and solidarity needed to be conveyed by education systems. '[E]ducation and training systems have to lead people to accept that racism and intolerance have no place in our society; that discrimination (...) is unacceptable' (Council of the European Union 2001). Education systems should transmit values of tolerance and equality. The most central, legally binding EU instrument adopted in this spirit is the Council Directive of 29 June 2000 implementing the principle of equal treatment between persons irrespective of racial and ethnic origin. It provides that the principle of non-discrimination should be guaranteed, especially in the field of education. It stresses that ' $[\mathrm{t}] \mathrm{o}$ ensure the development of democratic and tolerant societies which allow the participation of all persons irrespective of racial or ethnic origin, specific action in the field of discrimination based on racial or ethnic origin should go beyond access to employed and self-employed activities and cover areas such as education' (Council of the European Union, 2000).

One of the main characteristics of educational systems as described in the EU policy instruments advocating the potential of education to promote democracy is that it should be provided on an equal basis to all. The Council Directive (2000/43/EC) on equal treatment between persons irrespective of racial or ethnic origin cited above emphasises that the participation of all in society can only be achieved after receiving equal treatment in all fields, including education. Education should thus be provided in a non-discriminatory manner and all children should be treated on an equal footing in the education system. This notion is reflected in national legislation in some EU countries. For example, in Ireland, the Equal Status Acts of 2000 - 2004 are designed to promote equality of opportunity, prohibit discrimination on nine specific grounds, prohibit harassment on the discriminatory grounds and sexual harassment, require reasonable accommodation of people with disabilities and allow for positive action. The Acts require that schools do not discriminate across the nine grounds of gender, marital status, family status, sexual orientation, religion, age, disability, race and membership of the Traveler community (Department of Education and Science and Equality Authority, 2005). 
In spite of the values expressed in EU directives and some national legislation, actual attitudes in EU countries are still found to be xenophobic. For example, in 2005 the European Monitoring Centre on Racism and Xenophobia (EUMC) published the report Attitudes towards Migrants and Minorities in Europe. Drawing on data from the 1997, 2000 and 2003 Eurobarometer surveys amongst EU citizens aged 15 and above, as well as the 2003 European Social Survey, which included a number of questions on xenophobic and discriminatory attitudes in European societies, the research found that $60 \%$ of respondents in the EU-15 expressed the view that multiculturalism had certain limits, i.e. in relation to how many people of other races, religions or cultures a society can accept, an opinion that has increased significantly since 1997. This view was less explicit in the 10 new Member States (42\%). The Greeks (80\%), East Germans (75\%), Irish (72\%), West Germans (71\%) and British (68\%) most strongly supported the view that there are limits to a multicultural society whereas the Spanish (49\%), Italians (46\%), Swedes (41\%), Finnish (22\%) and most of the new Member States were less critical. In addition, the report showed that support for different forms of exclusion (i.e. resistance to a multicultural society, perceived limits to multicultural society, opposition to civil rights for legal migrants, favouring repatriation policies for legal migrants and for criminal migrants) was more prevalent amongst people with lower educational levels; economic prosperity appeared to lessen the perceived threat posed by immigrant minorities; and young people (aged 15 to 24) exhibited less support for ethnic exclusion than older people.

Given the changing nature of European society in general and the European classroom in particular, there is a consequent need for teachers to have the skills and competencies to deal effectively with this new environment. Phalet et al. (2004) point out that 'changes in the social and ethnic composition of student populations have far-reaching implications for educational psychology. Learning and teaching in multicultural classrooms pose a major challenge to both students and teachers (p. 60)'. Research in the United States with racially mixed classrooms has also identified similar issues. For example, Weisman and Garza (2002) point out that the world views of most white middle class teachers are based on their life experiences as members of the dominant group and they often minimize the reality of racism as well as disregard the knowledge and experiences that shape the lives of non-mainstream students. Other American research (Gay and Howard, 2010; Kumar and Hamer, 2012) found that there was a fear of diversity, stereotypic beliefs, and a resistance to dealing with race and racism frequently expressed by students in teacher education programmes. These findings 
were felt by the authors to underscore the need for more multicultural teacher education to enable teachers to work effectively with ethnically diverse students.

It was in this context of increasing diversity of classrooms across Europe that the present study was conceived and carried out. The larger study on which this article is based was carried out in the context of an EU Leonardo Project, designed to determine the skills and competences needed by teachers and trainers in the $21^{\text {st }}$ century with a view to improving professional development programmes (Fine-Davis et al., 2007). The purpose of the study was to learn more about the issues of equality and diversity in secondary education and vocational training. The ultimate aim of the study was to expand knowledge and awareness of diversity issues in the classroom and to provide information which could contribute to the professional development of teachers and trainers so that they might better cope with the increasing diversity in their classrooms and create an educational environment which was egalitarian and social inclusive. The strength of this study is that it compares teachers' and students' attitudes on a variety of diversity issues cross-nationally. It compares and contrasts the attitudes of these two groups towards non-national students, ethnic and religious minorities and disabled students and also explores and compares their attitudes to gender issues, bullying and other issues related to equality and diversity. Some information on attitudes towards diversity training was also elicited. In addition to comparing students' and teachers' attitudes, the paper also examines gender differences and country differences amongst students and teachers.

\section{Conceptual and methodological framework}

The two main concepts underpinning the design of this project are diversity and equality. In the questionnaires for students and teachers we operationalised the concept of 'diversity' as 'differences among people, such as sex (male/female), nationality, ethnic background, religion, disability, age, sexual orientation and so on." We defined 'equality' as "treating people in the same way, regardless of their background, and where necessary, making reasonable accommodation to their needs'.

As a preliminary step in the research designed to identify the key issues, two focus group discussions were held with teachers and students in each of the six countries for a total of 12 focus groups. The results were used as input to the development of the main questionnaire 
used in the study. The aim was to have a common core of questions for the students and teachers. The questionnaire was designed in such a way that a question asked of students was also asked of teachers, but from the latter's point of view. This enabled us to elicit reciprocal attitudes or 'mirror images' on a given question, which allowed us to compare attitudes of teachers with those of students.

The questionnaire was translated from English into French, Spanish, Italian and Latvian so as to be accessible to the subject populations in all of the participating countries. Each of the six partners contacted schools in their respective countries to obtain the sample of respondents. An information sheet about the study with instructions on how to respond online to the questionnaire was adapted and translated in each country and provided to the schools, with versions for each of the two respondent groups. The sample design for each country aimed to include 50 students and 50 teachers, both stratified by sex, for a total of 100 respondents in each country and 600 participants overall. The sample was also designed so as to include a proportion of foreign-born students, as well as some with disabilities, where possible.

The final sample consisted of 320 students and 208 teachers for a total of 528 respondents. The number of students and teachers is roughly evenly distributed among the six countries (apart from Italy which had somewhat fewer teachers) and there was also a good stratification of males and females in each of the groups in all countries, with the exception of Latvia, which did not have any female teachers. In approaching schools, it was easier to obtain student respondents and somewhat more difficult to obtain teachers since there were fewer of the latter group. There were also some difficulties in using the online questionnaire. In some cases paper questionnaires had to be used. A methodological caveat is in order here because it was not possible within the scope of this study to disentangle different types of otherness, including for instance how a native Italian Muslim, or Protestant, answers questions about the 'others'.

The majority of students $(77.7 \%)$ were between the ages of 16 and 18 years, with a mean age of 17.5 years. The majority $(61.8 \%)$ of teachers were over 40 years of age, though there were a fair number between 30 and 39 years of age (21.6\%). The age profile of male and female teachers was quite similar. The overwhelming majority of respondents, both teachers and students, were nationals of their own countries (92.4\% of students and $97.5 \%$ of teachers) and there were only a few non-nationals in the sample ( $7.6 \%$ of students and $2.5 \%$ of teachers). 
Most of the respondents were living in cities and towns. Approximately one third of students (37.7\%) were living in cities, and a somewhat larger group was living in towns $(39.3 \%)$. Much smaller proportions were living in villages or open country $(22.9 \%)$. Almost all of the respondents were in co-educational schools $(89.6 \%)$. The majority of students attended public, non-denominational schools. Those who were attending denominational schools were most likely to be in Ireland (64.2\% of the Irish sample) and to a lesser extent Italy.

\section{Results}

Attitudes to Equality and Diversity in the Classroom

In the introduction to the study following the definitions of equality and diversity, teachers were informed that "we would like to ask you about your attitudes and experiences as a teacher in relation to these issues. In particular, we would like you to tell us what you think teachers need in order to better promote equality in the classroom'. Students were informed that 'we would like you to tell us what you think teachers need to do in order to better promote equality in the classroom'. Both groups were told that the results would be fed into teacher training organisations and policy maker in all the countries taking part and also to the EU.

The questionnaire was very comprehensive and we are presenting here the selected highlights of the most important findings. Among the questions presented to students and teachers was a series of questions regarding different groups of people in their classrooms and if so, did this 'cause any difficulties in your classroom'? Results for both groups are presented below.

Firstly, students were asked if there were students in their classroom from outside the host country. Students from France and Ireland were most likely to say that this was the case $(98 \%$ in France and $91 \%$ in Ireland). Spanish students were next most likely to report having foreign-born classmates (72\%). In the UK, just over half of students $(57 \%)$ reported having foreign born classmates. The proportion was lower in Latvia (45\%) and the lowest in Italy $(23 \%)$. The Italian sample was from Sardinia, which may not be reflective of Italy as a whole. The majority of students (59.7\%) said that the presence of foreign-born students never caused difficulties. This was significantly more than the proportion of teachers who said 'never', 
which was only $32.2 \%$. Male students were more likely than females to see a problem $(9.1 \%$ compared to $1.4 \%$ ).

Analyses of variance (ANOVA) were carried out separately for students and teachers, with sex and country as the independent variables in each case. This was due to the very slight difference in phrasing of the questions for students and teachers. Table 1 presents results for students and teachers concerning the perceived difficulty of having foreign students in the classroom. There were no significant effects for gender; however there were significant main effects of country, both for students and for teachers. The mean scores for students and teachers by country are presented below in Table 1:

\section{---Insert Table 1 about here ---}

The fewest problems with foreign-born students were perceived by French students. Few problems were also perceived by students from the UK and Spain. The results for Spain corroborate the findings from the Eurobarometer surveys discussed earlier. Mirroring the percentage results, the scores for teachers were systematically higher than those of students in all countries, except for Italy, where teachers were less likely than students to perceive problems.

In relation to perceptions of having students from other ethnic, religious or racial groups in their classes, the results showed that students were also less likely than teachers across five of the six countries to perceive difficulties in having students from other ethnic, religious or racial groups in their classes. Italy is the exception, where teachers were less likely than students to perceive difficulties. However, it will be recalled that there were relatively few students from other ethnic, religious and racial groups in the schools in the Italian sample. Thus, the perceptions would seem to be based more on imagined difficulties than from actual experience. In countries where there is greater diversity in the classroom, such as in France, Spain, the UK and Ireland, the perception of difficulties is lower than in Italy and Latvia, where there is less experience of diversity.

---Insert Table 2 about here --- 
An analysis of variance was carried out in which gender was examined together with country, and significant gender differences were found across all countries. The mean score for male students was 1.8 and the mean score for female students was $1.5(\mathrm{~F}=4.05 ; \mathrm{p}<.05)$.

\section{Students' and Teachers' Attitudes to Students with Disabilities in their Classrooms}

The next issue addressed in relation to the diverse classroom had to do with disability. Students were asked if there were students with disabilities in their classrooms. The UK sample had the highest proportion of students saying that there were students with disabilities in their classes (40.7\%). About one fifth of students in Ireland (21.2\%) and Spain (19.2\%) said that they had students with disabilities in their classes. Relatively few students in Latvia, Italy and France said that there were students with disabilities in their classes $(9.6 \%$ in Latvia, $6.4 \%$ in Italy and only $1.8 \%$ in France). The overall percentage was $16.7 \%$ for all countries. It should be emphasised, as we have indicated above, that these proportions are merely indicative of the samples in each country; they do not indicate actual proportions in each country, since the samples were not representative of the countries in question.

A similar pattern emerged in relation to attitudes to students with disabilities in the classroom, namely that students were less likely than teachers to perceive difficulties when there were disabled students in their classes. As before, students were more likely to say having disabled students 'never' causes difficulties (76.8\% of students say this) than were their teachers, of whom only $33.6 \%$ said this 'never' caused difficulties.

A comparison by country shows that having students with disabilities is more likely to be perceived as problematic in Latvia $($ mean $=2.6)$ and in the UK $($ mean $=1.8)$ than in the other four countries, where the means range from 1.0 in France to 1.5 in Ireland $(F=5.88 ; p<.001)$ (see Table 3). It will be recalled that the UK sample had the highest incidence of students saying that they had fellow students with disabilities in their classes (40.7\%) and Latvia had one of the lowest incidences $(9.6 \%)$. Thus, the slightly higher UK mean score may reflect actual problems with students with disabilities, whereas the Latvian score would appear to be more likely to indicate an anticipation of difficulties, rather than actual difficulties. This interpretation would be in line with previous findings for Latvia, in which problems were more likely to be feared even when diverse groups were not present or were present in small numbers in the classroom. 
---Insert Table 3 about here ---

\section{Dealing with diversity issues: Mirror Images of Teachers and Students}

This study offered the opportunity to study perceptions from two vantage points, that of the student and that of the teacher. An important area was how well teachers were perceived to handle diversity issues. The vast majority of students thought their teachers were sensitive to the needs of foreign students. Almost two-thirds (64\%) agreed: $30 \%$ slightly agreed, $23.5 \%$ moderately agreed and $10.5 \%$ strongly agreed. A comparison by country showed that students from Italy, Ireland and the UK were most likely to say that teachers were sensitive to the needs of foreign students. Students in France, Latvia and Spain were less likely to think that their teachers were sensitive to the needs of foreign students (Table 4).

A comparison was carried out on the attitudes of foreign born students with other students on this item. It was found that the foreign born students were significantly less likely to think that their teachers were sensitive to the needs of foreign born students than were the other students $(\mathrm{F}=4.19 ; \mathrm{p}<.05)$. The mean score for foreign born students on this measure was 2.88 (with $3=$ slightly disagree) and the mean score for the rest of the students was 3.96 (with $4=$ slightly agree). The number of foreign born students was small $(n=23)$ so that this finding, while statistically significant, should be viewed with caution. Nevertheless, it suggests that the needs of foreign born students are not being optimally met by their teachers.

Teachers were somewhat more likely than students to positively assess the behaviour of their peers: $82 \%$ agreed that 'most teachers in our school are sensitive to the needs of foreign students', of whom 43\% agreed slightly, 19\% agreed moderately and $20 \%$ agreed strongly. Teachers in Ireland were the most positive in their assessment of their colleagues, followed by teachers in the UK and Italy. Teachers in France were least likely to rate their colleagues highly on this measure, corroborating the views of French students (Table 4). 
A similar question was asked of the two groups in the sample concerning perceived sensitivity of teachers to students with disabilities. Generally speaking, students were positive in their assessment of the sensitivity of their teachers in this sphere. Just under $80 \%$ of students agreed that 'my teachers are sensitive to the needs of students with disabilities'. Teachers themselves were slightly more likely to rate teachers as sensitive in this area $(87.5 \%)$. Generally speaking, teachers were more positive in their assessment of teachers' sensitivity to the needs of students with disabilities than students were. This was true in the UK, Ireland and Latvia. However, in France students were much more likely to give positive assessments of teachers (mean $=5.9$ out a possible 6 ) than teachers were to give of themselves (mean $=3.4)$. There was a slight tendency for this to be true in Italy as well. In Spain students and teachers were in agreement, with both having a mean score of 4.3 out of a possible 6 (see Table 5).

---Insert Table 5 about here ---

After ascertaining perceived sensitivity of their teachers towards various groups, students were asked the more global question, 'How well do you think your teachers handle problems in the area of equality and diversity?' Teachers were asked the mirror image question, 'How well do you think you handle problems in the area of equality and diversity?' Generally speaking, both students and teachers felt that teachers handled equality and diversity issues well: $45 \%$ of students said teachers handled such issues 'well' and an additional $7.6 \%$ said they handled them 'very well'. However, $37 \%$ of students felt their teachers only handled such issues 'so-so' and $10.3 \%$ felt they handled either poorly or very poorly. Teachers were somewhat more positive in their assessments of how well they themselves handled equality and diversity issues. Over half (52\%) said they handled them 'well' and a further 7\% said they handled them 'very well'.

There were significant country differences among teachers on these questions. Teachers in Ireland $($ mean $=3.9)$, Spain $($ mean $=3.8)$ and the UK $($ mean $=3.7)$ were more likely to think they handled equality and diversity issues well, whereas teachers in Latvia (mean = 3.1) Italy and France $($ mean $=3.3)$ were less likely to think so. 
Discrimination on the basis of gender was tapped through questions on the use of sexist language by teachers, gender stereotypes in teaching materials and the relative career prospects of male and female students.

Teachers and students were asked whether or not they thought teachers sometimes used sexist or stereotyped language in the classroom. Thirty-six per cent of students across all countries felt that their teachers sometimes did. Of these, 21.5\% slightly agreed, $10.3 \%$ moderately agreed and only $4.5 \%$ strongly agreed. Male students were more likely to agree than females (42\% males vs. $32.5 \%$ females). There also were significant country differences on this among students. Sexist and stereotyped language was more commonly perceived by students in Latvia and the UK and less so in Italy. Spain, France, and Ireland fell in between. Among teachers, females were more likely to think teachers in general used sexist and stereotyped language than male teachers were. Almost $40 \%$ of female teachers thought so compared to only $30 \%$ of male teachers; however, this difference was not statistically significant. While it is not surprising that female teachers might be more attuned to this, it is surprising that male students were more attuned to it than female students.

A related question was asked concerning whether the images and language of some teaching materials reinforced gender stereotypes. Students (34\%) were more likely to perceive gender stereotypes in the images and languages of teaching materials than were their teachers, of whom $26.3 \%$ were aware. Female students and teachers were more attuned to this than male students and teachers. However, these differences were not statistically significant for either group. There was a significant effect for country, however. Latvian students were the most likely to perceive gender stereotypes in teaching materials.

Several questions were asked concerning career prospects of boys and girls in secondary school in order to assess and compare the perceptions of students - both male and female and teachers - both male and female. Teachers and students were most likely to think that boys and girls had equal career prospects. Over two thirds of students (68.3\%) agreed with this statement, as did $59 \%$ of teachers. Only $29 \%$ of teachers and students thought that boys had better career prospects than girls. Male students were more likely than female students to 
think that boys had better career prospects. Fewer students $(23 \%)$ and teachers $(17 \%)$ thought that girls had better career prospects than boys.

When asked their views on whether they thought students were directed into traditional jobs, students more likely than teachers think so with $36.6 \%$ of students and $17 \%$ of teachers agreeing that this was the case. Students in Latvia, Italy or France were significantly more likely to think they were directed to traditional jobs than were students in the UK, Spain and Ireland. On the whole, teachers were less likely than students to think that students were directed to traditional jobs. There was quite a lot of uniformity over the countries.

\section{Bullying in the Classroom}

Bullying is seen as an important issue in secondary school classrooms across Europe. This has been a topic of increasing concern and one which was felt to be important to examine in detail. More than half of the male students in the sample $(64.3 \%)$ said that bullying was an issue, of whom $48 \%$ said it was a problem 'to some extent' and a further $17.3 \%$ of whom said it was 'a great deal'. Female students also saw it as an important issue, but slightly less so than did males: $44 \%$ of female students said it was a problem 'to some extent' and a further $6.6 \%$ said it was 'a great deal'. Teachers also acknowledged bullying as a problem. Overall, $58.8 \%$ of male and $57 \%$ of female teachers saw it as a problem, with most saying it was a problem 'to some extent'.

The fact that male students saw bullying as a more serious problem is very likely related to a greater experience of bullying than girls (mean male students $=3.8$; mean female students $=$ $3.1 ; \mathrm{F}=18.9 ; \mathrm{p}<.001)$. Students in Italy were most likely to say that boys experience more bullying than girls $($ mean $=4.4)$, followed by Latvia $($ mean $=3.7, F=7.25 ; p<.001)$.

Bullying occurred for a variety of reasons, including being a foreign national, ethnic background and religion and due to sexual orientation. While $57 \%$ of students said that in their school people are sometimes bullied because of their sexual orientation, only $35.7 \%$ of teachers agreed that this was the case. Similarly a higher proportion of students perceived bullying due to being a foreign national. Ethnic background was seen as a cause of bullying by $43.3 \%$ of students and only $37.6 \%$ of teachers. Being of another religion was seen as a cause of bullying by $35.6 \%$ of students, but only $18 \%$ of teachers. These data would appear to 
reflect a lesser awareness of the prevalence and causes of bullying on the part of teachers, which would suggest that they may be out of touch with the painful experiences of their students.

There were also significant country differences for both students and teachers in terms of perceptions of bullying based on sexual orientation. French students were the most likely to perceive bullying in their schools based on sexual orientation followed by the UK. Spain, Italy and Ireland were similar and Latvia reported less bullying based on sexual orientation. Generally speaking, teachers were less aware of bullying based on sexual orientation. This was true in all countries except in Italy, where teachers were more aware of this than their students. In general, female teachers expressed a greater perception of bullying based on sexual orientation did their male peers.

Bullying based on students' ethnic background was most likely to be reported by Irish students and also by Irish teachers. It was least likely to be reported by Italian and Latvian students. When students and teachers were asked if their schools did enough to combat bullying, teachers were almost twice as likely to say 'yes' than students were. This was particularly true of male teachers. While only $37.9 \%$ of students said 'yes', $64.4 \%$ of teachers said 'yes', however male teachers were much more likely to say so $(70.2 \%)$ than female teachers were $(58.2 \%)$. There were no notable sex differences among the students. What was noteworthy, however, was that almost a third of students said they did not know.

\section{Issues and Teaching Techniques in a Diverse Classroom}

Finally, the study examined how important various factors were for teachers in managing diversity in their classroom. Was a lack of resources an issue or perhaps a need for more training in the area of diversity? Was it the fact that students had language difficulties and/or different levels of ability? Was it due to conflict between different groups in the classroom? Was there a need for more support from management? We presented teachers with seven possible factors and asked them to indicate on a 7-point scale, ranging from 1 (very unimportant) to 7 (very important), how important each of the factors was for them in managing diversity in their classroom. 
Teachers rated the 'need for training' on their part the most significant factor in managing diversity in their classroom. Quite a sizeable proportion (41.3\%) said this was "very important'. The second most important issue for teachers was the fact that there were different levels of student ability; $36.8 \%$ of teachers saw this issue as 'very important'. Language difficulties of students were also cited as very important by $30.2 \%$ of teachers. Almost half $(44.8 \%)$ of teachers were of the view that foreign students did not get enough support with the language of their new country.

A lack of resources was also seen as a very important factor in managing diversity by almost a third of teachers. In addition, a quarter indicated that support from management was very important. When asked about the level of management support they received in order to manage diversity, less than half of teachers felt that there was 'sufficient management support' while 52\% felt there was insufficient support. Teachers in the UK and Latvia were more likely to perceive support from management in the area of diversity, as compared with those in Italy, Ireland, Spain or France. In all countries, males were more likely to perceive management support than were females.

Adapting teaching methods is one way of dealing with diverse groups in the classroom. Most teachers $(89 \%)$ agreed that it was important to do so. Teachers felt that students with disabilities were the most in need of adaptation of teaching methods; approximately $50 \%$ believed this was 'very important'. The next most important groups were students from different countries, and different religious and ethnic groups. Just under one third of teachers said this was so. Adapting teaching methods was seen as less important in relation to gender issues.

When asked how often they actually adapted their teaching materials and methods to various groups, the majority said they did. Female teachers were more likely than male teachers to say that they did this often or always. While $60 \%$ of female teachers said they adapted their materials and methods to diverse groups either 'often' or 'always', this was in contrast to just $45 \%$ of male teachers who did so. Lack of resources and lack of time were the most important reasons given for not adapting teaching methods, with over a third of male teachers citing these. Lack of training was the next most important reason given. Female teachers tended to cite lack of time and lack of training, and were less likely than their male counterparts to cite lack of resources. There was general consensus among teachers that adapting teaching 
methods to diverse groups and cultures increased their workload too much: $67.5 \%$ of teachers agreed either slightly, moderately or strongly with this. There were no gender differences in this, although teachers in Ireland, the UK and Spain were more likely to say that adapting their teaching methods to diverse groups increased their workload, than were teachers in France.

\section{Professional Training and Development in Equality and Diversity}

Almost half (46.8\%) of the teachers said that their initial training had included no training in equality or diversity issues, $42.4 \%$ said it included these topics 'to some extent' and $10.8 \%$ said they received 'a great deal' of training in this area. There were significant country differences in this area, with the greatest reported training in Italy and the UK. The remaining four countries provided significantly less training in this area.

When asked if they had received any continuous training or personal development in equality and diversity, the majority (66.2\%) of teachers said they had received 'none at all' or 'very little', 28.4\% had received 'a fair amount' and a small fraction (5.5\%) said they had received "a great deal" of training in equality and diversity. Teachers in the UK were the most likely to report having had continuous training in equality and diversity issues, with Italian and Spanish teachers also more likely to report continuous training in this area. Teachers from France, Ireland and Latvia were less likely to report having received continuous training in equality and diversity. The UK score was notably higher than the other countries, suggesting that continuous training in equality and diversity is given a priority in the UK.

Most of the teachers felt that they could benefit from further training in the area of equality and diversity: $60 \%$ felt they could benefit 'to some extent' and $27.5 \%$ 'a great deal', and only $12 \%$ felt they would not benefit at all from such training. Overall, these findings indicate receptivity among teachers to continuous training in equality and diversity, but with reservations. It would appear that cost considerations are a barrier and there is also quite a lack of knowledge about continuous training.

Teachers were asked to indicate what their priority areas would be in a training course in equality and diversity. They were presented with 10 different areas and asked to rate the 
importance of these on a seven point scale. Communication skills were rated most highly, with $47 \%$ rating this as 'very important'. Training in Conflict Resolution skills was also seen as very important by $41.7 \%$, followed by training in Behaviour Management in the Classroom.

Teachers also expressed a strong need for more training in Teaching the Native Language to Foreign Students $-37.9 \%$ indicated that this was 'very important'. Approximately 30\% said that Better Knowledge of other Cultures was 'very important' as was Competence in Equality and Diversity. The data overall would seem to indicate that ethnic, racial and national diversity are causing more problems for teachers than gender diversity, and in particular that skills in communication, conflict resolution and behaviour management are particularly needed.

\section{Conclusions}

The study has presented mirror image views of students and teachers towards equality and diversity issues in the classroom in six countries of the European Community. The findings demonstrate the positive attitudes of students to diversity in their classrooms and the fact that there was a consistent gap between the attitudes of students and teachers. These results are encouraging in the sense that they indicate generally positive attitudes among young people towards the increasing diversity in our society. Our findings corroborate the Eurobarometer surveys which showed that younger people (15-24) had more positive attitudes towards diversity than older people (European Monitoring Centre on Racism and Xenophobia, 2005). Our findings further found that in countries where there is greater diversity in the classroom, such as in France, Spain, the UK and Ireland, the perception of difficulties is lower than in Italy and Latvia, where there is less experience of diversity. This is encouraging in the sense that greater diversity and intergroup contact is resulting in more inclusive attitudes in schools. Nevertheless, bullying, often based on intergroup differences, was identified as a problem experienced in all of the countries. The results comparing students with teachers identified consistent differences in perceptions between these groups, with teachers having greater estimates of difficulties posed by diversity, together with smaller estimates of bullying behaviour. These perceptual differences need to be addressed so as to ensure the well-being of students. It is clear that a significant proportion of teachers have deficits in their initial professional training in the area of equality and diversity and a large proportion are not 
rectifying these deficits through ongoing professional training. While teachers do perceive some barriers to undertaking continuous training, they generally express receptivity to such training and to obtaining greater skills in the area of equality and diversity. This study has identified some of the areas which should be included in such ongoing training in order to promote a more inclusive classroom. 


\section{References}

Allen R., Dawson G., Wheatley K., and White, C.S. (2004). Diversity Practices: Learning Responses for Modern Organisation. Development and Learning in Organisations, $18(6), 13-15$.

Bagshaw, M. (2004). Is diversity divisive? Industrial and Commercial Training, 36(4),15357.

Barrett, A. and Y. McCarthy (2008). Immigrants and Welfare Programmes. Oxford Review of Economic Policy, 24(3), 542-59.

Brenke, K. and Zimmermann, K.F. (2007). Zuwanderung aus Mittel- und Osteuropa trotz Arbeitsmarktbarrieren deutlich gestiegen. DIW Wochenbericht, 44, 645-53.

Buchmann, C. and Parrado, E.A. (2006). Educational achievement of immigrant-origin and native students: a comparative analysis informed by institutional theory. International Perspectives on Education and Society, 7, 345-77.

Carrell, M., Elbert, N. and Hatfield, R. (2000). Human Resource Management: Strategies for managing a diverse and global workforce, Orlando: Dryden.

Council of the European Union (2000). Council directive 2000/43/EC of 29 June 2000 implementing the principle of equal treatment between persons irrespective of racial or ethnic origin. Official Journal of the European Union L 180.

Council of the European Union (2001) The Concrete Future Objectives of Education and Training Systems. Report from the Education Council to the European Council, 5980/01 EDUC 23.

Department of Education and Science and The Equality Authority (2005) Schools and the Equal Status Acts, Dublin: Department of Education and Science and the Equality Authority.

European Monitoring Centre on Racism and Xenophobia (2005). Attitudes Towards Migrants and Minorities in Europe. Wien, Manz Crossmedia.

Eurydice (2004). Integrating Immigrant Children into Schools in Europe, Brussels: EACEA.

Eurydice (2009). Integrating Immigrant Children into Schools in Europe: Measures to Foster Communication with Immigrant Families and Heritage Language for Immigrant Children. Brussels, EACEA.

Faas, D. (2010) Negotiating Political Identities: Multiethnic Schools and Youth in Europe, Farnham: Ashgate.

Faas, D. (2011) The Nation, Europe and Migration: A comparison of geography, history and citizenship education curricula in Greece, Germany and England, Journal of Curriculum Studies 43(4): 471-92.

Faas, D., Hajisoteriou, C. and Angelides, P. (2013) Intercultural education in Europe: Policies, practices and trends, British Educational Research Journal (forthcoming).

Fassmann, H. (2009). Diversity Policy in Employment and Service Provision: Case study Vienna, Austria. Strasbourg, Report for Cities for Local Integration Policy.

Fine-Davis, M., Craven, C. and Holzworth, A. - in collaboration with Mayer, G., Herrón, A., Sánchez, M., Novell, E., González, R., Martín T., Walker, J., Gooding, J., Carrolaggi, P., Simola, S., Manca, S, Kalnina, R and Upmane, M. (2007) Equality and Diversity in the European Classroom: A Six Country Study. Final Report to the EU Leonardo Da Vinci Programme. Trinity College Dublin and Balear de Desarrollo y Formación, Spain. 
Fine-Davis, M., McCarthy, M., Edge, G., and O’Dwyer, C. (2005a) Work-Life Balance and Social Inclusion in Ireland: Results of a Nationwide Survey. Dublin: National FlexiWork Partnership (Centre for Gender and Women's Studies, Trinity College Dublin; IBEC; ICTU; FÂS, Age Action Ireland and Aware).

Fine-Davis, M., McCarthy, M., Edge, G. and O'Dywer, C. (2005b) Mental Health and Employment: Promoting Social Inclusion in the Workforce. Dublin: National FlexiWork Partnership (Centre for Gender and Women's Studies, Trinity College Dublin; IBEC; ICTU; FÁS, Age Action Ireland and Aware).

Fix, M., Papademetriou, D.G., Batalova, J., Terrazas, A., Yi-Ying Lin, S. and Mittelstadt, M. (2009) Migration and the Global Recession. Washington DC, Migration Policy Institute.

Garreta Bochaca, J. (2006). Ethnic Minorities and the Spanish and Catalan Educational Systems: From Exclusion to Intercultural Education. International Journal of Intercultural Relations, 30, 261-29.

Gay, G. and Howard, T. C. (2000). Multicultural teacher education for the $21^{\text {st }}$ century. The Teacher Educator, 36 (1), 1-16 (published online 2010).

Gundara, J.S. and Jacobs, S. (Eds) (2000). Intercultural Europe: Diversity and Social Policy. Farnham, Ashgate.

Heckmann, F. (2008). Education and Migration: Strategies for Integrating Migrant Children in European Schools and Societies. Brussels, European Commission.

Jackson, R., Miedema, S., Weisse, W. and Willaime, J.-P. (Eds) (2007). Religion and Education in Europe: Developments, Contexts and Debates, Müter: Waxmann.

Kahanec, M. and Zimmermann, K.F. (2009). Migration in an Enlarged EU: a challenging solution? European Commission Economic Papers 363.

Knauth, T., Jozsa, D.-P., Bertram-Troost, G. and Ipgrave, J. (Eds.) (2008). Encountering Religious Pluralism in School and Society: A Qualitative Study of Teenage Perspectives in Europe. Münster, Waxmann.

Koopmans, R., Statham, P., Giugni, M., Passy, F. (2005). Contested Citizenship: Immigration and Cultural Diversity in Europe. Minneapolis, University of Minnesota Press.

Kumar, R. and Hamer, L. (2012) Preservice Teachers' Attitudes and Beliefs toward Student Diversity and Proposed Instructional Practices: A Sequential Design Study, Journal of Teacher Education, 64(2), 162-177.

Nusche, D. (2009). What Works in Migrant Education? A Review of Evidence and Policy Options. OECD Education Working Paper No. 22.

Organisation for Economic Cooperation and Development (2006). Where Immigrant Students Succeed: a comparative review of performance and engagement in PISA 2003. Paris, OECD.

Organisation for Economic Cooperation and Development (2010). Closing the Gap for Immigrant Students: policies, practice and performance. Paris, OECD.

Papademetriou, D.G., Sumption,M. and Terrazas, A. (2010). Migration and Immigrants Two Years after the Financial Collapse: Where Do We Stand? Washington DC, Migration Policy Institute.

Phalet, K., Andriessen, I. and Lens, W. (2004) How Future Goals Enhance Motivation and Learning in Multicultural Classrooms, Educational Psychology Review, 16(1), 59-89.

Ruhs, M. (2009). Ireland: From Rapid Immigration to Recession. Migration Policy Institute, http://www.migrationinformation.org/Feature/display.cfm?ID $=740$

Saji, B. (2004). Workforce diversity, temporal dimensions and team performance. Cross Cultural Management, 11(4), 40-59. 
Schofield, J.W. (2006). Migration Background, Minority-Group Membership and Academic Achievement: Research Evidence from Social, Educational and Developmental Psychology. WZB Berlin.

Tikly, L., Haynes, J., Cabellero, C., Hill, J. and Gillborn, D. (2006). Evaluation of Aiming High: African Caribbean Achievement Project, http://www.dfes.gov.uk/research/data/uploadfiles/RR801.pdf

Valk, P., Bertram-Troost, G., Friederici, M. and Béraud, C. (Eds) (2009). Teenagers' Perspectives on the Role of Religion in their Lives, Schools and Societies: A European Quantitative Study. Münster, Waxmann.

Weisman, E. M. and Garza, S. A. (2002). Preservice Teacher Attitudes toward Diversity: Can one class make a difference? Equity and Excellence in Education, 35(1), 28-34 
Table 1: Students' and Teachers' Perceptions of Whether Students from Countries other than the Host Country caused Difficulties in the Classroom: Means by Country $(\mathrm{N}=377)$

\begin{tabular}{|l|c|c|}
\hline Country & $\begin{array}{c}\text { Students } \\
(\mathrm{n}=231)\end{array}$ & $\begin{array}{c}\text { Teachers } \\
(\mathrm{n}=146)\end{array}$ \\
\hline France & 1.2 & 1.5 \\
\hline Spain & 1.5 & 2.2 \\
\hline UK & 1.4 & 2.1 \\
\hline Italy & 2.1 & 1.3 \\
\hline Ireland & 1.9 & 2.6 \\
\hline Latvia & 2.3 & 3.0 \\
\hline
\end{tabular}

$(1=$ never; $5=$ always $) \quad \mathrm{F}=8.49 ; \mathrm{p}<.001 \quad \mathrm{~F}=6.3 ; \mathrm{p}<.001$ 
Table 2: Students' and Teachers' Perceptions of Whether Presence of Students from other Ethnic, Religious and Racial Groups caused Difficulties in the Classroom: Means by Country $(\mathrm{N}=360)$

\begin{tabular}{|l|c|c|}
\hline Country & $\begin{array}{c}\text { Students } \\
(\mathrm{n}=201)\end{array}$ & $\begin{array}{c}\text { Teachers } \\
(\mathrm{n}=159)\end{array}$ \\
\hline France & 1.2 & 1.4 \\
\hline Spain & 1.4 & 1.9 \\
\hline UK & 1.5 & 1.9 \\
\hline Italy & 2.1 & 1.4 \\
\hline Ireland & 1.7 & 2.6 \\
\hline Latvia & 2.0 & 2.5 \\
\hline (1= never; 5 = always) & $\mathrm{F}=3.14 ; \mathrm{p}<.05$ & $\mathrm{~F}=9.64 ; \mathrm{p}<.001$
\end{tabular}


Table 3: Students' Perceptions of Whether Presence of Students with Disabilities caused Difficulties in the Classroom: Means by Country

\begin{tabular}{|l|c|}
\hline Country & $\begin{array}{c}\text { Students } \\
(\mathrm{n}=137)\end{array}$ \\
\hline France & 1.0 \\
\hline Spain & 1.2 \\
\hline UK & 1.8 \\
\hline Italy & 1.0 \\
\hline Ireland & 1.5 \\
\hline Latvia & 2.6 \\
\hline (1=never; 5 = always) & $\mathrm{F}=5.88 ; \mathrm{p}<.001$
\end{tabular}


Table 4: Students' and Teachers' Perceptions of Teachers' Sensitivity toward the Needs of Foreign Students $(\mathrm{N}=475)$

\begin{tabular}{|l|c|c|c|c|}
\hline \multirow{2}{*}{} & \multicolumn{3}{|c|}{$\begin{array}{c}\text { Students } \\
(\mathbf{n}=\mathbf{2 7 5})\end{array}$} & \multirow{2}{*}{$\begin{array}{c}\text { Teachers } \\
(\mathbf{n}=\mathbf{2 0 0})\end{array}$} \\
\cline { 2 - 4 } & $\begin{array}{c}\text { Males } \\
(\mathrm{n}=107)\end{array}$ & $\begin{array}{c}\text { Females } \\
(\mathrm{n}=168)\end{array}$ & $\begin{array}{c}\text { Total } \\
(\mathrm{n}=275)\end{array}$ & 3.5 \\
\hline France & 4.0 & 2.8 & 3.4 & 4.1 \\
\hline Spain & 3.4 & 4.0 & 3.7 & 4.6 \\
\hline Italy & 3.9 & 4.3 & 4.0 & 4.5 \\
\hline Ireland & 4.4 & 4.6 & 4.5 & 4.9 \\
\hline Latvia & 3.9 & 4.7 & 4.3 & 4.2 \\
\hline
\end{tabular}

( $1=$ Strongly Disagree, $6=$ Strongly Agree)

$\mathrm{F}=4.10 ; \mathrm{p}<.001$ Main Effect of Country (Students)

$\mathrm{F}=3.12 ; \mathrm{p}<.01 \quad$ Interaction Effect of Country and Gender (Students)

$\mathrm{F}=5.85 ; \mathrm{p}<.001 \quad$ Main Effect of Country (Teachers) 
Table 5: Students' and Teachers' Perceptions of Teachers' Sensitivity toward the Needs of Students with Disabilities: Means by Country $(\mathrm{N}=462)$

\begin{tabular}{|l|c|c|}
\hline Country & $\begin{array}{c}\text { Students } \\
(\mathrm{n}=263)\end{array}$ & $\begin{array}{c}\text { Teachers } \\
(\mathrm{n}=199)\end{array}$ \\
\hline France & 5.9 & 3.4 \\
\hline Spain & 4.3 & 4.3 \\
\hline UK & 4.3 & 5.2 \\
\hline Italy & 5.2 & 5 \\
\hline Ireland & 4.4 & 5 \\
\hline Latvia & 3.9 & 4.4 \\
\hline \multicolumn{2}{|c|}{$\mathrm{F}=4.22 ; \mathrm{p}<.01$} & $\mathrm{~F}=12.70 ; \mathrm{p}<.001$
\end{tabular}

( $1=$ strongly disagree; $6=$ strongly agree $)$ 